\title{
Langkah-Langkah untuk Menemukan Investor Start-Up Berbasis Teknologi
}

\author{
Anna Maria Tansah \\ Program Studi Kewirausahaan \\ Universitas Bina Nusantara \\ anna.tansah@binus.ac.id
}

Seorang pejuang start-up yang berbasis teknologi terutama website dan aplikasi mungkin akan mengalami masa kesusahan dalam menemukan sumber dana permodalan untuk memulai start-upnya. Karena bisa dikatakan start-up website dan aplikasi bisa menghabiskan dana yang terbilang tidak sedikit hanya untuk memulai start-up ini. Banyak founder start-up aplikasi hanya berhenti sampai pembuatan ide dan business plan saja sehingga belum bisa menjadikan start-upnya menjadi kenyataan. Berikut merupakan langkah-langkah yang dapat calon founder start-up website dan aplikasi coba untuk mendapatkan investor untuk pendanaan start-upmu.

Pertama, tentukan dulu ide bisnismu. Dalam menentukan ide bisnis yang perlu dilakukan adalah pertama berfokus pada tiga sumber baru yang paling umum dan juga beberapa teknik yang dilakukan pengusaha dalam mengeksplorasi sumber-sumber ide tersebut dan menjadikannya sebuah ide yang baru, kedua menggunakan alat yang disebut first screening dimana alat ini digunakan untuk menentukan apakah ide tersebut menjadi potensi peluang ide bisnis yang baru dan layak (Barringer, 2015).

Kedua, tindakan yang harus dilakukan adalah membuat Business Plan Idea StartUp karyamu menarik dan dapat meyakinkan calon investor nantinya. Agar, suatu business plan menjadi efektif ketika akan diimplementasikan, maka dalam menulis business plan harus diterapkan yaitu ringkasan, industri, perusahaan dan produk yang ditawarkan, analisa dan penelitian pasar, ekonomi bisnis, rencana pemasaran, rencana desain dan pengembangan, rencana produksi dan operasional, tim manajemen, rencana keseluruhan, resiko utama, masalah dan asumsi, rencana keuangan, pengajuan penawaran perusahaan, dan lampiran (Setiarini, 2013). Hal ini sangatlah penting karena investor akan menilai kelayakan usaha bisnismu dari business plan yang telah kamu buat.

Ketiga, mencari calon Investormu. Jika kamu seorang dari latar belakang keluarga yang kaya maka kamu bisa mengajukan business planmu kepada keluargamu yang bisa menjadi Angel Investormu. Angel investor biasanya adalah individu atau kelompok yang berinvestasi di perusahaan start-up atau perusahaan tahap awal dengan imbalan kepemilikan ekuitas (Harroch, 2019). Jika latar belakangmu bukan dari keluarga orang kaya maka kamu dapat mengikuti pitching competition dan juga melakukan pitching di depan VCF (Venture Capital Fund). VCF bersedia membiayai inovasi yang masih ada risiko teknologi tinggi, tetapi sering kali menyertakan potensi 
tinggi sebagai imbalannya (Siregar et al., 2020). Jika mereka tertarik dengan ide bisnis dan kelayakan usahamu maka kamu sudah bisa mengajukan proposal pendanaan sesuai dengan financial plan pada bagian business plan milikmu.

\section{References}

Barringer, B.R. (2015). Preparing Effective Business Plans: An Entrepreneurial Approach (2nd ed.). Pearson Education Limited.

Harroch, R. (2019). Startup Financing: 5 Key Funding Options For Your Company. Forbes. Retrieved November 16, 2021, from https://www.forbes.com/sites/allbusiness/2019/12/22/startup-financing-keyoptions/?sh=23614a0a2a84

Setiarini, S.E. (2013). Business Plan sebagai Implementasi Kewirausahaan pada Pembelajaran Ekonomi di SMA. Dinamika Pendidikan, 8(2), 146-155. https://journal.unnes.ac.id/nju/index.php/DP/article/view/3370

Siregar, D., Purnomo, A., Mastuti, R., Napitupulu, D., Sadalia, I., Sutiksno, D. U., Putra, S. H., Sahir, S. H., Revida, E., \& Simarmata, J. (2020). Technopreneurship: Strategi dan Inovasi. Yayasan Kita Menulis.

https://kitamenulis.id/2020/04/13/technopreneurship-strategi-dan-inovasi/

\section{Biografi}

\section{Anna Maria Tansah}

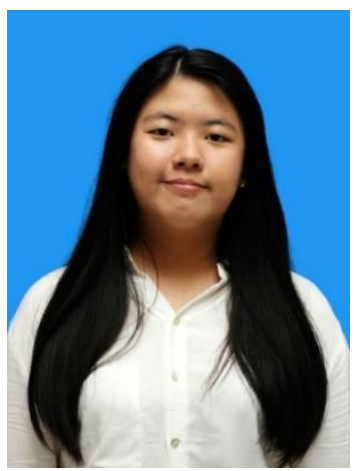

Penulis kelahiran Denpasar ini adalah seorang mahasiswa program studi kewirausahaan di Universitas Bina Nusantara, kampus Malang sejak tahun 2020. Anna sedang menjalankan usaha onlinenya di bidang kesehatan di E-commerce. Mempunyai hobi bermain bulu tangkis dan suka sekali dengan makan.

Email: anna.tansah@binus.ac.id Instagram: @annaa_tnsh 